\title{
LIFE VS. PERFORMANCE: DECONSTRUCTING DEPRESSION, GRIEF AND SUICIDAL IDEATION
}

Yves Gore

I found Dunedin meditative and heartbreakingly beautiful.

Having just lost my older sister a year ago to cancer, the mysterious darkness of the city was mothering my wounds. The brokenness in me doesn't stop hurting, but the Gothic arcs of Otago's Victorian-era architecture were like a timeless affinity to my melancholy. The age of the buildings encapsulates memories of people over the centuries who lived and died in the city. Somehow this transitory energy normalises my grief and made me okay with it.

With the darkness of the city having my back, this made my residency at Dunedin School of Art a highly relevant period in my personal and creative journey. The history of the town has a way of suspending depression and suicidal ideation from my mind, and allowed me to study them with some distance and humour, even when I hit the lowest point every now and then.

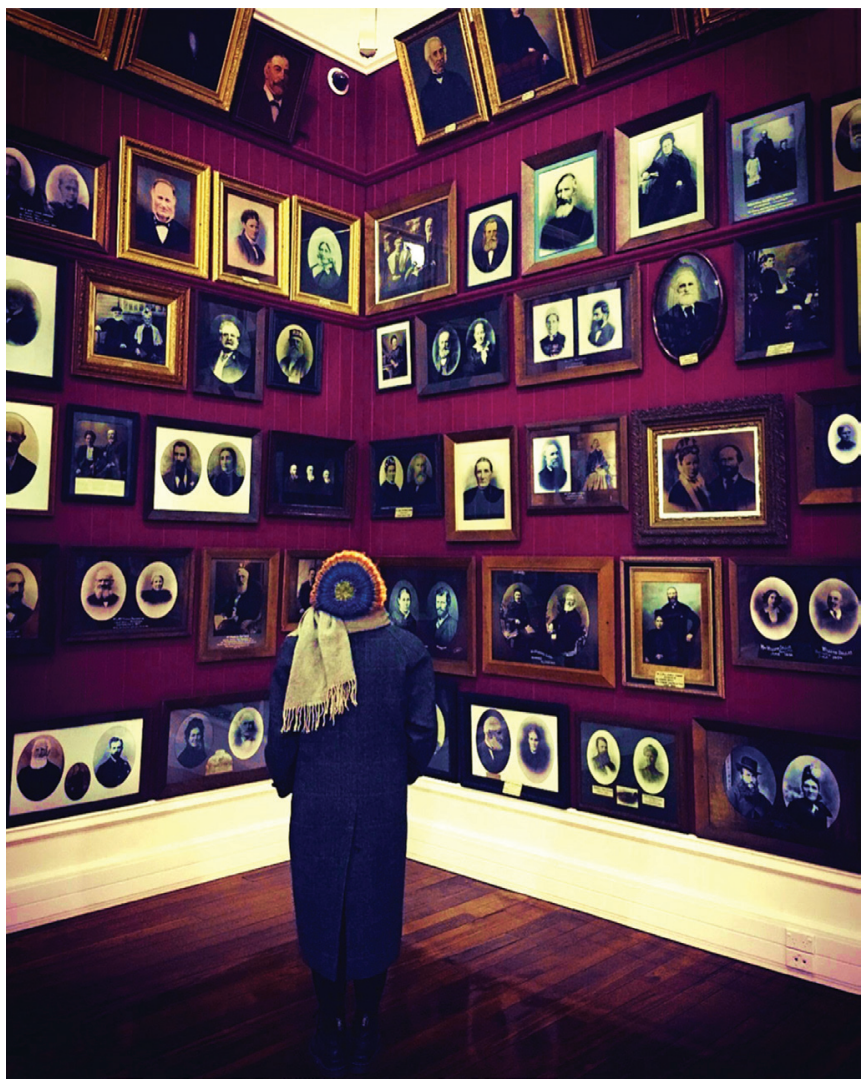

Figure I.Yves Gore at Toitū Otago Settlers Museum, studying the faces of Dunedin's past residents. Image: Frank Fu.

One of the features of clinical depression is that, if you aren't feeling suicidal or overly obsessed about someone or something, you can become extremely apathetic and unmotivated. Whether your life is perfect or a mess, whether you are working or on holiday, healthy or ill, depression doesn't care. It hits you when it wants to.

So, during the six weeks of my art residency, I was prepared to not let the first or the last symptom get to me. Because if I had killed myself at the school's Art House, that would be an unfair mess for my long-time collaboratorl 


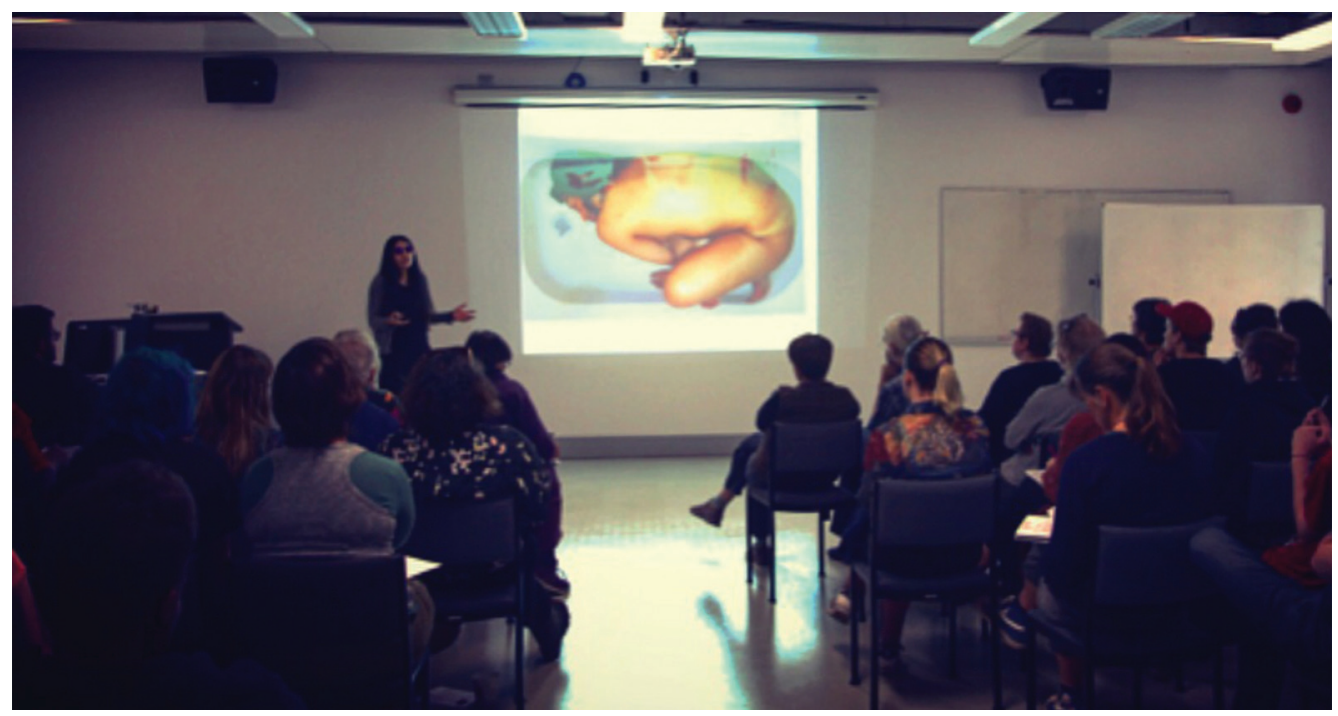

Figure 2. A slide from Yves Gore's public seminar at Dunedin School of Art. Seeing a photograph of herself in a bathtub in a suicidal and debilitative state transformed her relationship with the illness. Image: Frank Fu.

husband/co-residency artist, Frank Fu, to clean up. It would also be unfair to the students and staff for me to become an awful reminder of such gruesomeness, every time they get to school to begin a normal day, not to mention the inconsolable pain my grieving family and friends will have to go through again.

Also, if I had gone onto the other spectrum by becoming extremely unmotivated, six weeks could go by in a snap and that would be an irresponsible waste of time, resources and economic investment, which the school had decided to make in me when they chose to have me as an artist in residence.

With this line of thinking, depressed or not, I decided to prove to Dunedin School of Art that they've made the best decision by having me. My first priority was to have our visit make a difference to the student and staff experience. What could Frank and I offer which could make a positive impact on the students' perspectives on their own creative journey, present and future?

From my previous experiences of hanging out with fellow artists from various backgrounds, the questions that often come up are things like: how does one manage his or her problems in life and still practice art? What tools are available in the contemporary era that we can utilise to help our art become discoverable and find like-minded peers unrestricted by geography? With these points of reference, I realised that my position as a performance artist working in Los Angeles, with some international creative collaboration and exhibition experience, was an insightful angle I could share and discuss with the students. So I decided to give my compulsory seminar on "Artist with Issues," a lecture focusing on issue management surrounding my depression and career management, and Frank decided to give his lecture on "Who Does the Artist Think She Is?," which focuses on his journey as a performance artist, and how he found his identity as a creator who couldn't stay away from themes like intervention and the politics of the art world.

We also programmed additional events for our residency. This included film screenings of Orange Confucius and Whiskey Tango Forest, directed by Frank Fu, with myself and artist Ralph Paine as the main subjects for each film; daily performances at the school which the students and staff could participate in if they liked; and lastly, two performance art events, one each from Frank and myself. 
Frank scheduled his performance, FLUXFU, during a global performative festival in Dunedin called Equinox. FLUXFU is a Fluxus' movement with a FU twist, where Frank brings his actions from museums and galleries into public spaces for a general audience to experience and participate in. Often, he deals with themes like the politics of the art world, and FLUXFU is a continous world happening across different time zones and locations.

For my performance however, it took some personal exploration for me to come to the clarity I

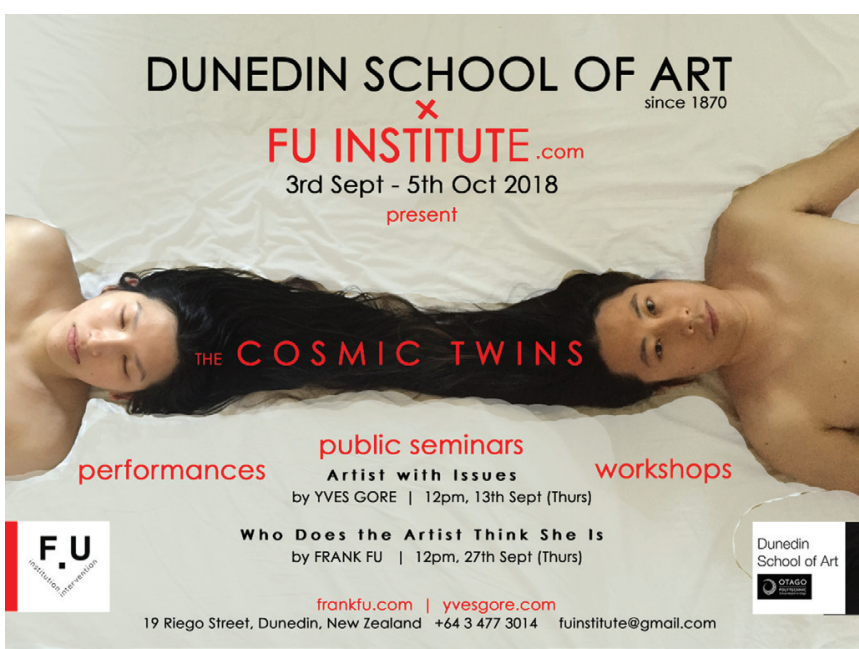

Figure 3. Lobby card of Dunedin School of Art x F.U. Institute, with details of Yves Gore and Frank Fu's residency events at the school. Poster:Yves Gore. needed to decide on what to perform. I started by considering the emotional discomforts in my life at that time and recalled three instances: the shame of being viewed as a bad daughter; the shame arising from looking disheveled during heavy depression; and lastly, the taboo of dying young.

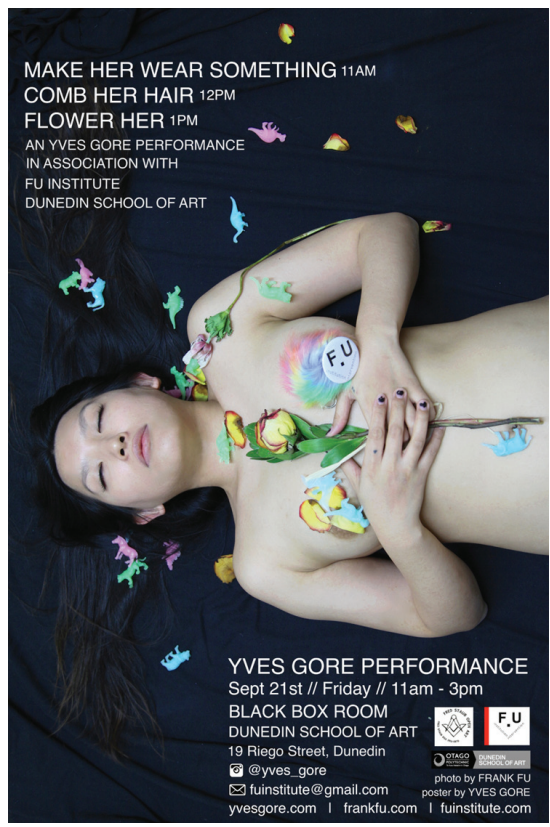

Figure 4.Yves Gore's performance poster for MAKE HER WEAR SOMETHING / COMB HER HAIR / FLOWER HER.

Image: Frank Fu. Poster:Yves Gore.
With this in mind, I decided to use performance art to transcend these emotions, firstly for myself, and bonus points if others got something from it too. I came up with a threehour performance, in three parts, titled MAKE HER WEAR SOMETHING / COMB HER HAIR / FLOWER HER (Fig. 4)

I decided on a ritualistic, ceremonial vibe and asked Frank to dress in a dark-coloured onesie, his long hair tied back, wearing the rose-tinted glasses that I usually wear, to mirror me in real life and emphasise the gist of our Cosmic Twins energy.

At the beginning of the performance, he'd ring the bell and then ring it again at the end of every hour. Along with the ringing, Frank would chant a self-composed gothic and ritualistic prayer. Frank also found a dark space called the Black Box Room and we thought it was perfect for the performance.

The first part, "MAKE HER WEAR SOMETHING" (Fig. 5), is inspired by my penchant for nudity in both real life and performance. In the film Orange Confucius, directed by Frank Fu, I appeared nude, and after it screened at film festivals my relatives and friends learned by word of mouth that I was having sex on screen and not wearing very much. They were appalled by my actions and started telling my parents to "make her wear something." 
Although it doesn't bother my parents that I do nude art, conventional body politics whereby women cannot display their genitals or sexuality to the public made me feel like an abnormal child who has let her parents down for doing 'shameful' things. I still relish the freedom of nudity, and I still believe our private parts can be public, but at that point in time, I couldn't get rid of this shadow at the back of my mind that I am a bad daughter.

How does this performance help? First, I titled it "MAKE HER WEAR SOMETHING" to frame the shame inherent in the statement and attempt to invert

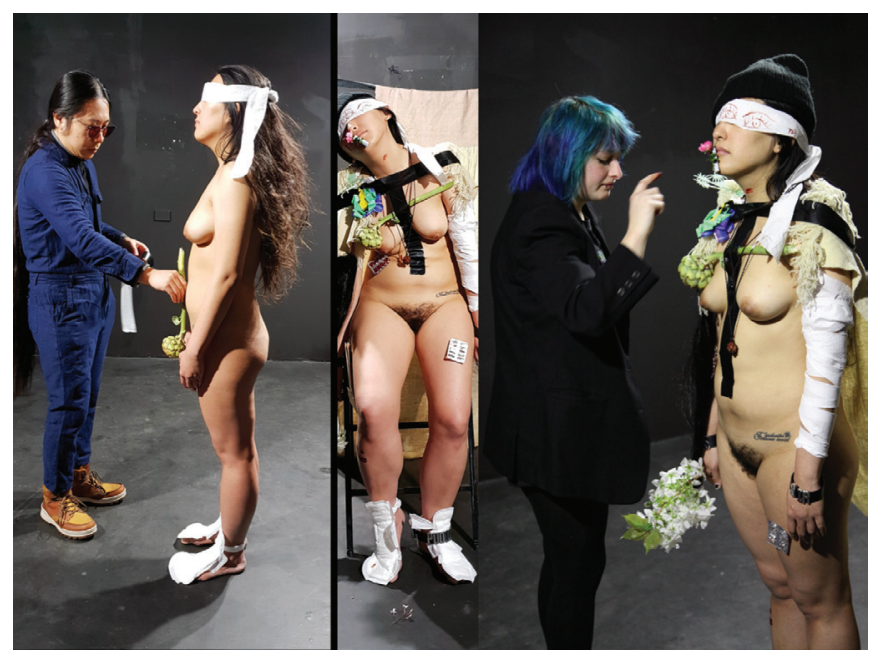

Figure 5.Yves Gore performing in "MAKE HER WEAR SOMETHING." Image credits: Michael Greaves (left); Carlos Cabrera (centre and right). it into a joke. I left instructions

for participants on a sign, letting them know that they could bring anything they like for me to wear. This included clothing, artworks, trash, to any random trinkets they desired.

At the end, even by the third act of the performance, the Kiwi audience did surprise me! Because they didn't cover me up very much. And even better, they made me look fashionable, and this transcended my shame, turning it into a form of empowerment. From a wool cape to toilet paper and period pads, to the pill packaging from antidepressants, I was pleasantly surprised by the artful, humorous getup I was wearing when I opened my eyes after finishing the performance.

I also heard someone yell, "Wow! She's really naked." As if our bodies have become so censored in society that it becomes unreal to see a nude person.

The second part of my performance was titled "COMB HER HAIR" (Figs 6-7). This piece stemmed from a memory I had growing up, where I had long, unruly, tangled hair, as a kid. Being born with depression, if no one brushed my hair that day, I wasn't like other little girls who would proactively make their own hair neat and tidy. I would leave it the way it was - tangled. Even when I was a teen, people would yell at me, ordering some adults close by to "comb her hair!"

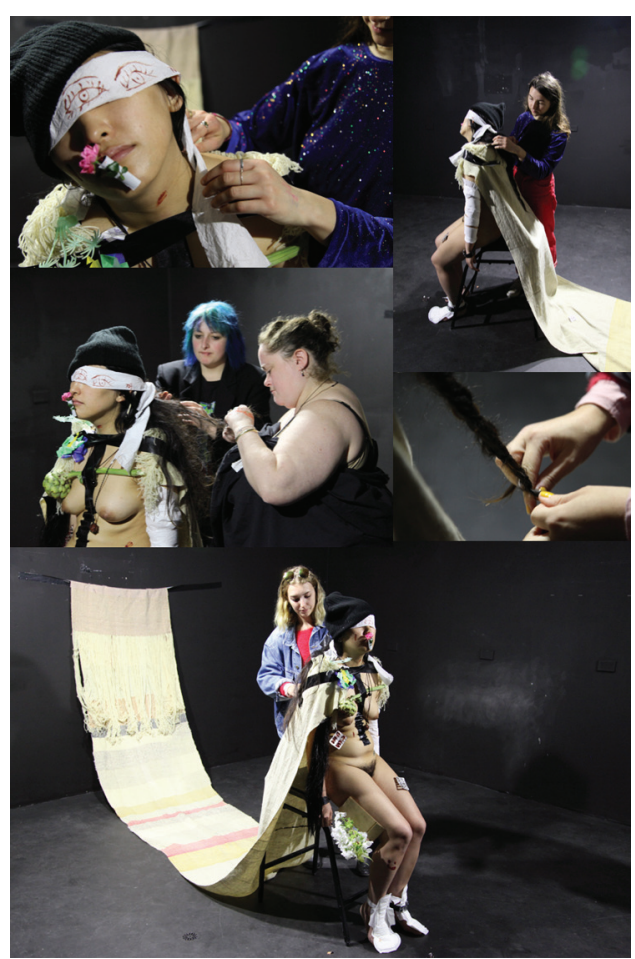

Figure 6. Yves Gore performing in "COMB HER HAIR," with (top to bottom) Nona Shackleton, Chey Webster, Andrea Muggeridge and Phoebe Storr. Images: Carlos Cabrera. 
Sometimes I would try my best to brush my own hair, but it wouldn't be anywhere as tidy as the others. Despite my efforts, relatives would still point at me and yell the same statement, "COMB HER HAIR!"

Again, framing this shame in a title, I invited the audience to do anything they wished with my hair. The subtext was: anything they do to my hair will be better than whatever I could do to it.

To make it truly realistic, in depression-fashion, I left my hair untouched for five days, and by the time I did the performance my locks were fully knotted up and the participants would need to work through it hard in order to really comb my hair. Barely any of the participants had patience for this task - most would spent around a minute on my hair, give up and exit the performance space.

But then there were a few special individuals - Chey, Andrea, Phoebe, Nona (Fig.6) - who each spent a decent amount of time patiently untangling my hair, making beautiful braids out of it.

After the performance, I asked them what made them take their time. They talked about their encounters with depression, with Phoebe in particular mentioning that she recognised it from my unruly hair. She wished that when she couldn't groom herself or do her daily chores, that someone would pick up where she had left off without a word. That simple thing would have made her feel better, and she wanted to do it for me.

This is an insight that came out of the performance. That someone without the illness would be impatient when a depressed person is slow, unproductive or not cleaning up after themselves, and would label this behaviour as lazy. Most of the time, it takes someone with the same illness or experience to empathise with the other and take the time to help them.

Another moving thing that came out of the performance related to an artist named Deb Fleming, who had brought two ceramic needles she had made specifically for the performance and put them in my hair (Fig. 7).

After the performance, I managed to track Debbie down for a one-on-one conversation at her studio.

I asked, why needles? She told me that needles are a symbol of repairing what is broken, that we can move on. She also added that she had a son who died by suicide, so depression is a subject close to home for her. Knowing that I have the illness, she said she hoped that the ceramic needles she made for me would be there to mend my emotional wounds. Strangely, that statement in itself is very healing for me, and till today I have kept the needles close.

Also, during the week after the performance, an artist came up to me and said that she had overheard a debate at her studio the day before, when a fellow artist had called my performance bullshit because he believed depression is bullshit and doesn't actually exist. This sparked an argument with another artist who told him that she would have been dead if she didn't take her antidepressants, so how can depression be bullshit?

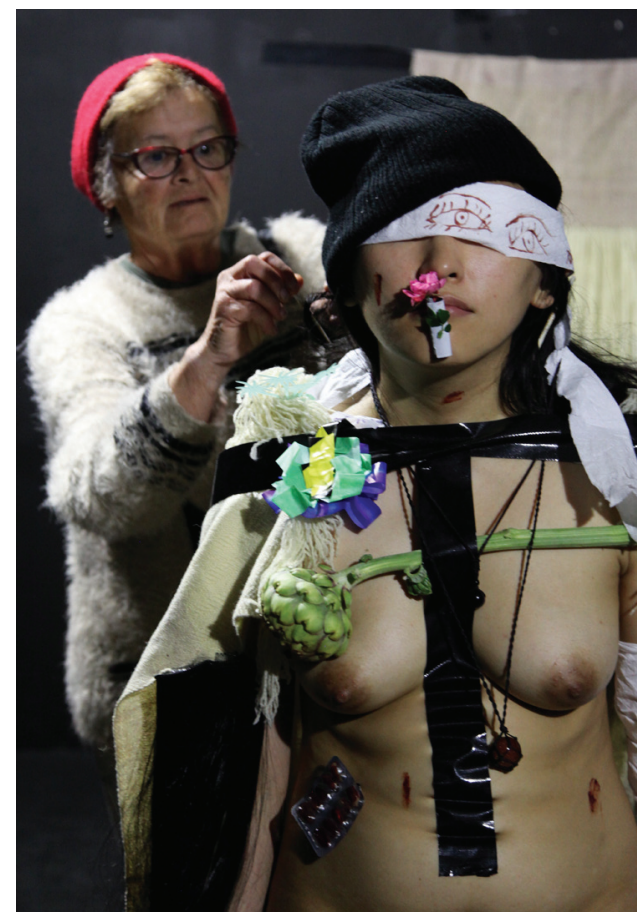

Figure 7.Yves Gore performing in "FLOWER HER," with Deb Fleming putting ceramic needles in Yves's hair. Images: Carlos Cabrera. 
This made me feel that despite the struggles and uncertainty I felt while executing this performance, it was worthwhile because after it someone had managed to stand up firmly and say that her depression does exist and let her experience be known to others oblivious to it. Because depression is such an invisible illness, so often it is dismissed by those who don't feel it. When a friend kills himself or herself, I would so frequently hear the statement, "But he/she doesn't look depressed!'

If we can keep having an open conversation about our feelings, and not be dismissive of things we aren't experiencing ourselves, maybe there will be better social support for depression. So we wouldn't have to wait till our loved ones killed themselves to find out that they'd been suffering all this time in silence.

The third part of my performance was called "FLOWER HER" (Figs 8-9). The idea for this performance first came to me when I was organising my late sister's funeral. The cost of

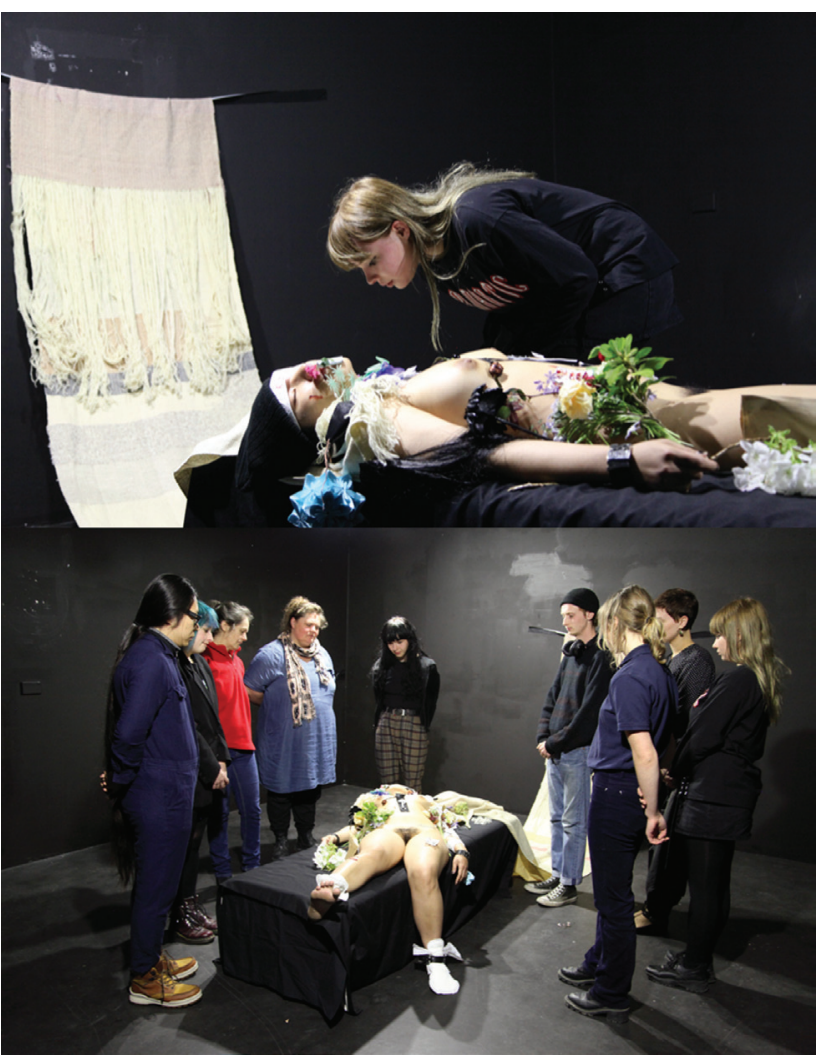

Figure 8.Yves Gore performing in "FLOWER HER." Images: Carlos Cabrera.

the wake was $N Z \$ 30,000$ and l'd never seen so many of our friends and family all gather in one place, so many of them saying nice things about my sister, things she probably would have appreciated very much if she were still alive to hear them. The funeral - like all funerals around the world - seemed like it was for the living to mend their broken hearts and console each other, not really for my dead sister.

Although her Kiwisaver covered the funeral costs, the experience left me wondering how we would experience our lives differently if we had our funerals while we were alive. We could share what we feel and think more deliberately with each other, instead of waiting until one of us is dead.

I wanted to hear things about me uncensored, and to feel my own funeral and death. Even more, I hope to break the taboo and fear of dying, for myself.

Those attending this part of the performance were free to bring an offering in the form of flowers, which could be natural or artificial, and say anything to me, positive or negative, uncensored. Since most of the participants were artists, they went as far as using the materials they make art their with to make the flowers, including cement, fabric, ceramics and latex (Fig. 10).

Death has greeted me every morning for as long as I have lived, taunting me each day with the possibility of which loved ones he might take from me. However, never have I been so close to Death as when I was lying on a coffinlike platform, with Frank chanting a funereal chant. 


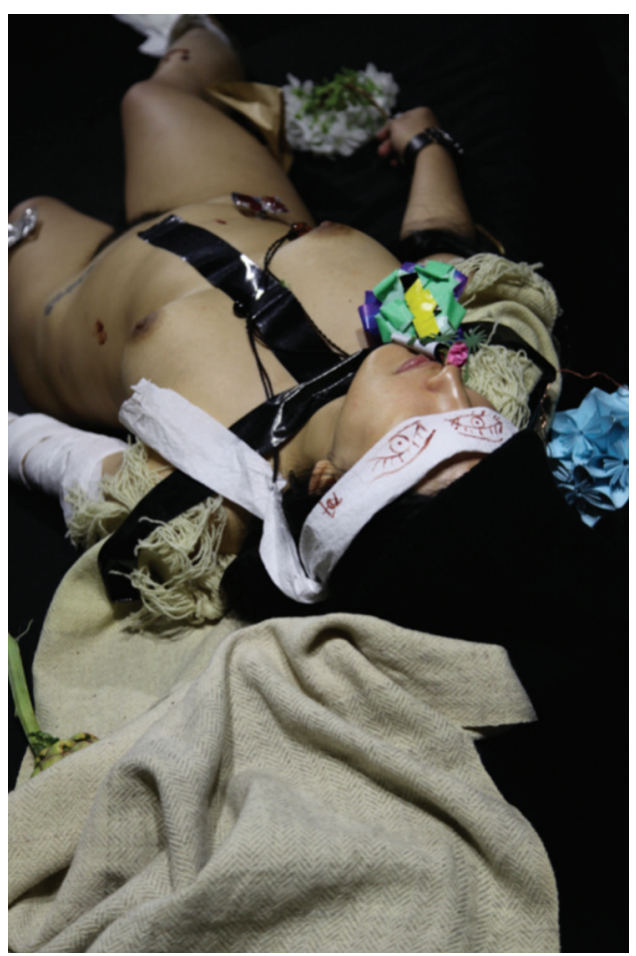

Figure 9.Yves Gore performing in "FLOWER HER." Image: Carlos Cabrera.
At the beginning of the performance, I felt a sense of fear and sadness, as if I had actually died but my senses were still engaged. I could hear, feel and see the yellowish vibe of the room, and when the first bouquet of wild picked flowers touched my skin, I felt a sense of warmth. The voice that followed this asked "Yves, are you in there?"

I found out later that an artist called Caleb said these words. He told me that he thought I had really died for the performance, because he felt the morbidness of the space when he walked in and it didn't look like I was breathing. He had to ask to make sure I was okay, and said when he saw me blink through the gap in the toilet paper around my eyes, that was a sign of relief for him

Do we have a biological instinct to fear all things that look dead? Or is that a socially instilled safety barrier, passed down through the generations, whereby we refrain from being too close to someone who has died, so that the disease or animal that killed them will not kill us too?

Another instance that moved me during the performance was when a dear friend, Alyss, came up to my ear and said in a sweet whisper that grew into a shout, "Yves, you are lovely, but sometimes you are too fucking loud for me!"

That honesty made me smile. And when Alyss's fiancée, Thomaso, came over and said to me,"Here's a flower made out of rubbish" (Alyss makes planes out of repurposed styrofoam), I thought how lucky am I to hear such witty sarcasm at my own 'funeral.'

During this performance, the moment that was most difficult for me was when Frank came over with his fully fledged eulogy and knelt beside me. His shaky voice broke my heart, especially when he said it would be difficult for him to move on, that he had enjoyed our journey together very much, and that he is proud of what I have become and for me to rest well. We were both quietly sobbing by that point. One of the rules for this performance was that I wouldn't speak or move, so all the internalised emotions were even more strongly felt and strangely affective and hyperreal.
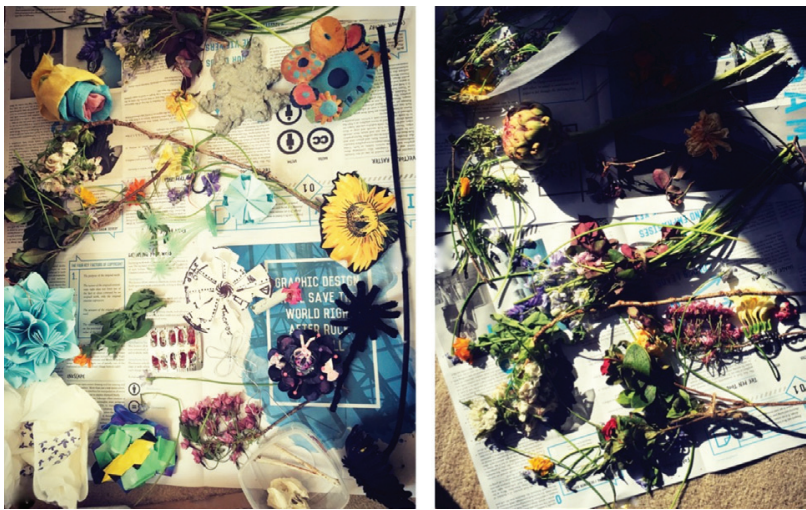

Figure 10. Flowers contributed to Yves Gore's performance in MAKE HER WEAR SOMETHING / COMB HER HAIR / FLOWER HER.

Image:Yves Gore. 
When the performance ended, it was as if the fear of dying had left me. Like I had reached the other side of existence, post-death. There was a sense of liberty, as if a rite of passage we used to dread had now come and gone, so that I can now live beyond the boundaries of death, as if death doesn't have command over me anymore.

When I opened my eyes to see the amazing creativity and love bestowd on this performance, I felt blessed to have such a truly curious and engaged group of participants. I wouldn't have been able to transcend these dark emotions if it were not for everyone putting their heart into being part of it. For the feedback and responses I've shared in this contribution, thank you all for giving me permission to share them.

I'm also grateful for the friendships that extend beyond Dunedin. We still keep in close contact, and I am also collaborating on a comic book project with one of the artists. In hindsight, it was wonderful how we could find family in the most unexpected places. I discoverded that depression was one of the uniting factors with my peers. Because many of us suffer from it, somehow we ended up being on the same wavelength and having the same artistic vision, and bonded together stronger.

Many times, a student and her mother whom we befriended at school, Hope and Beth, would frequently beckon us into their car to whisk us away to cool places in the middle of the night.

One evening, they took us to the infamous giant tooth sculpture, Harbour Mouth Molars, by Wellington artist Regan Gentry, which apparently many Dunedin residents hated (Fig. I I, bottom left). Quite the contrary for me, however - I truly feel for all things toothy and loved those tooth sculptures very much. I thought the work gave Mother Earth a set of teeth so that she could be more relatable to us, including how we are burning her up alive.

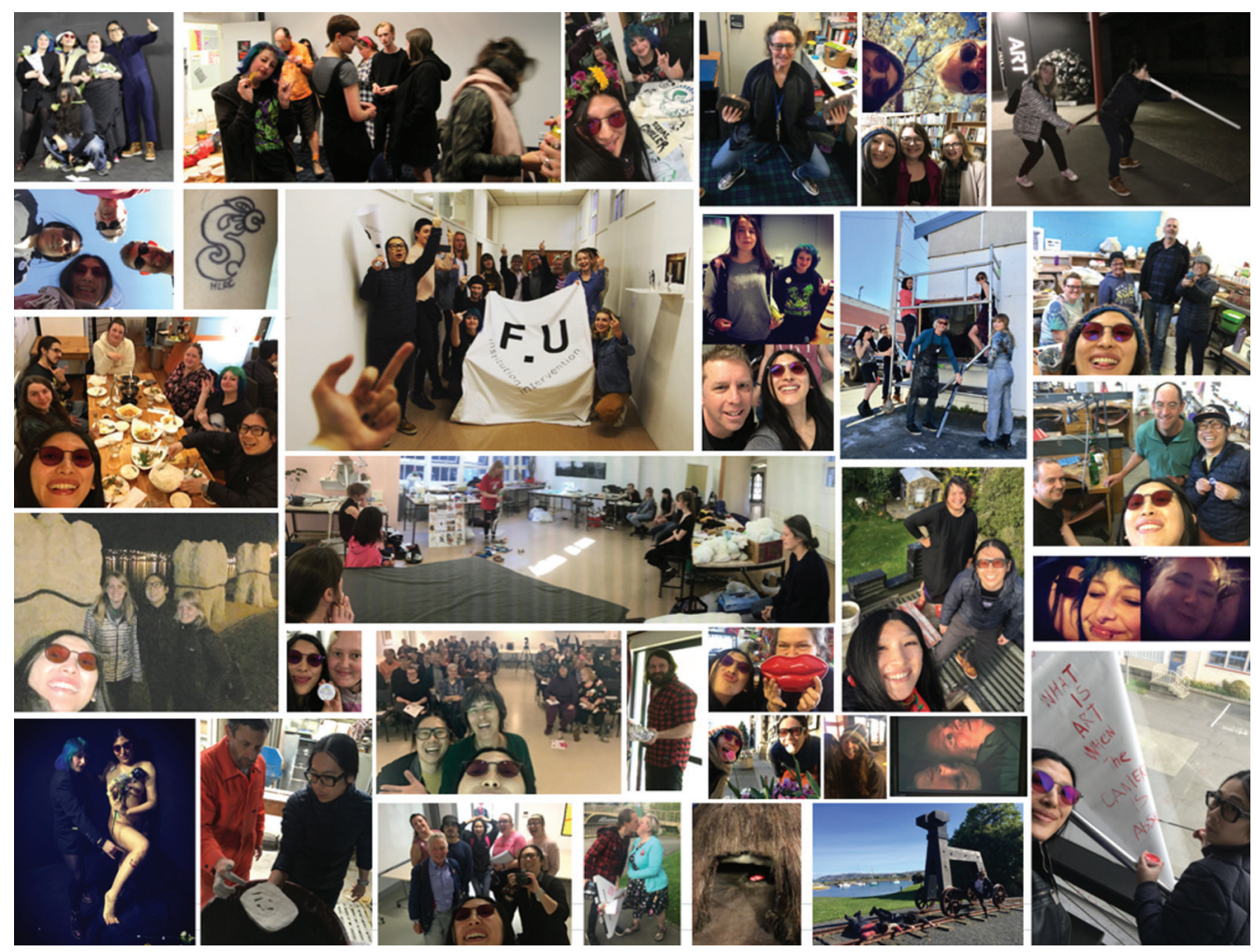

Figure I I. F.U. Institute $\times$ Dunedin School of Art in a nutshell. 
The night ended strangely however, as amid our laughter, Hope's mother, Beth, sensitive to something wrong in the air, started walking towards a car parked by the shore, with a whimpering sound coming from it. We stopped laughing. Worried about her safety, we followed her to find a woman and a man in the car, her door open. Beth courageously walked up to her and hugged her.We watched silently for the next half hour as Beth got the upset woman to finally speak. I turned out that she was suicidal as her husband, the man beside her, had been with another woman, and she wanted to kill herself that night.

Beth, being the sensitive but tough woman that she is, decided that we should accompany the woman and her husband to the hospital psychiatric department to get medical help. We followed her lead, and she stayed in the car with the woman while the husband drove, and I was in the front seat. Hope and Frank took her mom's car and followed from behind. As soon as we reached the hospital, the staff told Beth that she couldn't stay with the woman who needed her support, as she wasn't directly related to her. So we left the woman with her husband as she gazed at Beth one last time as she walked away.

This was close to home for me. I have therapy sessions with my psychologist and psychiatrist, and also group therapy, but I have never been to a psychiatric ward before, so I asked Beth why she had displayed such a strong instinct to take the woman to ER. Beth wrinkled her eyebrows and said that many people have killed themselves, as her son's former girlfriend had done just last week. Suicidal thoughts can be as serious as a heart attack, yet New Zealand and the rest of the world has yet to recognise this. We all learned how to recognise it that night, in ourselves and others, from Beth's sensitivity, and aso the need to be there for each other and to act on our instincts.

Last month, I did a performance as part of my residency in Norway, called LOVE HATE. A young man came up to me after the performance ended and, coincidentally enough, we talked about suicide and my experience of depression. I told him that I still struggled with it daily, but had made a deal with myself - that I could make art or I could kill myself and never live to know these interesting experiences in life and in art.

I wouldn't have come to this conclusion if not for my time in Dunedin. I was at the end of the world, full of darkness, but because of art and the people I met on this journey, I know it's worth hanging in there. Keep our sense of wonder, keep our eyes peeled! Because some gifts in life are hidden, waiting for us to discover them - if only we can resist the spells that our emotions can sometimes cast over us, spells that deprive us of sight, and learn to see through them.

Yves Gore is a performance artist and scifi-horror writer. She was born on Borneo Island, grew up in Auckland and is based in Los Angeles. She has an eternal fascination with death, non-binary gender, ecological preservation, undead creatures and nu-metal music. She can be found living in goth communities, not fitting in but happy to be herself and ending up finding companionship with others in exile.

I "ArtTerm - FLUXUS," https://www.tate.org.uk/art/art-terms/f/fluxus (accessed I3 July 2019).

Editor's Note: I acknowledge that many artists struggle with suicide and other mental health issues and that this article talks openly about this. Reading this may trigger a strong response in some people and so we are including the following national help line number.

0800543354 or text "help" to 4357 